\title{
Editorial
}

\section{THE FIRST CONFIRMED CASES OF COVID-19 IN INDONESIAN CITIZENS}

\author{
Ramadhan Tosepu*, Devi Savitri Effendy, La Ode Ali Imran Ahmad \\ Faculty of Public Health, University of Halu Oleo, Indonesia
}

Received: 13 May 2020| Accepted: 18 May 2020

DOI: https://dx.doi.org/10.36685/phi.v6i2.337

Corresponding author:

Dr. Ramadhan Tosepu

Email: ramadhan.tosepu@uho.ac.id

Copyright: (c) 2020 the author(s). This is an open-access article distributed under the terms of the Creative Commons Attribution Non-Commercial License, which permits unrestricted non-commercial use, distribution, and reproduction in any medium, provided the original work is properly cited.

Coronavirus Disease 2019 or Covid-19 was first identified in Wuhan, Central Hubei province, China. More than 200 cases of coronavirus infection and 3 deaths were reported (Parry, 2020). Majority of patients with pneumonia were caused by variables associated with seafood wholesale market in Wuhan, China (Zhu et al., 2020). There is no effective way to fight the virus, and personal hygiene is one step to avoid the spread of Covid-19 (Lai, Tang, Chau, Fung, \& Li, 2020). Common symptoms of Covid-19 include fever, respiratory problems, and lung infiltration (Strzelecki, 2020). World Health Organization (2020) stated that Covid-19 is an outbreak case, which is continually reported in various countries (Huang et al., 2020).

Figure 1 shows that the Indonesian citizens who were infected by Covid-19 came from various countries, including 1 Indonesian in Singapore, 9 in Japan, and 2 in Indonesia. The case detail of each country is described in the following.

\section{Singapore}

The Ministry of Health said that an Indonesian citizen with positive Covid-19 in Singapore was infected from his employer. He had no history of traveling outside Singapore (Ministry of Health of the Republic of Indonesia). On 18 February 2020, the Singapore Ministry of Health said that the
Indonesian citizen who was declared as the $21^{\text {st }}$ positive case of Covid-19 in Singapore was from the Yong Thai Hang medical shop cluster on 4 February 2020. Fortunately, he was then declared cured with negative lab result and discharged from the hospital (Ministry of Foreign Affairs of the Republic of Indonesia, 2020).

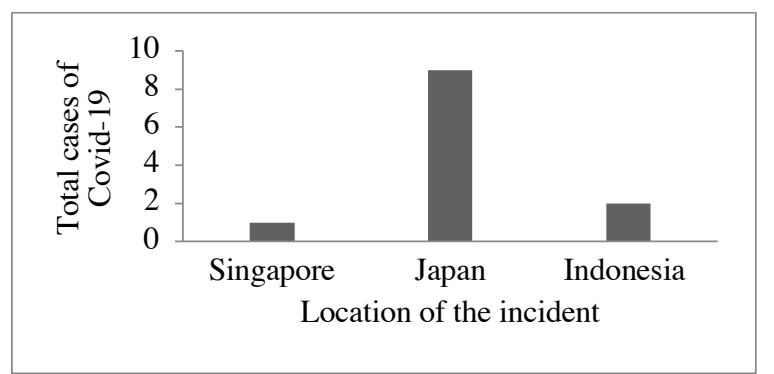

Figure 1 Indonesian citizens affected by Covid-19 based on the locations of the incidents

\section{Japan}

There were nine Indonesian citizens with positive Covid-19 in Japan. They were all crews of the Diamond Princess cruises from a total of 78 Indonesian citizens. They were treated in hospitals in the cities of Chiba and Tokyo (Ministry of Foreign Affairs of the Republic of Indonesia, 2020). Those who were closely contacted with them were then being isolated and closely observed. 


\section{Indonesia}

On 6 March 2020, the Indonesian government announced the first case of Covid-19 in Indonesia. The transmission of the virus was originated from a visit of Japanese citizens who were living in Malaysia to Indonesia. Before being tested positive for Covid-19, the 31-year-old woman was detected dancing with that Japanese citizen at a place in the Paloma club on 14 February 2020. Two days later, this woman experienced a cough and she went to an outpatient treatment at a hospital. But ten days later, the cough had not disappeared and she asked to be treated at the hospital. On 28 February 2020, the Japanese citizen called from Malaysia to tell the women that he was tested positive for Covid-19 and being treated in Malaysia.

This case presentation is to describe how the Indonesian citizens were infected at the first place. However, the outbreak control to reduce transmission needs to be done thoroughly. At-risk populations should receive serious attention so that they remain protected from the spread of Covid-19 (Li et al., 2020). Any efforts related to lockdown policies to stop the transmission should be implemented (Wang, Horby, Hayden, \& Gao, 2020), especially in Indonesia as a tropical country with large population and mobility that are potentially to be infected with Covid-19. It is therefore suggested for the government to improve health controls at Indonesian entrances to prevent the spread of the virus, early detection system (Indonesia Public Health Association, 2020), reduce mobility, and ask the community to work together to combat Covid-19.

Declaration Conflicting Interest

The authors declare that they have no conflict of interest.
References

Huang, C., Wang, Y., Li, X., Ren, L., Zhao, J., Hu, Y., . . . $\mathrm{Gu}, \mathrm{X}$. (2020). Clinical features of patients infected with 2019 novel coronavirus in Wuhan, China. The Lancet, 395(10223), 497-506.

Indonesia Public Health Association. (2020). Early warning of the Coronavirus. Jakarta: Indonesia Public Health Association

Lai, T. H., Tang, E. W., Chau, S. K., Fung, K. S., \& Li, K. K. (2020). Stepping up infection control measures in ophthalmology during the novel coronavirus outbreak: an experience from Hong Kong. Graefe's Archive for Clinical and Experimental Ophthalmology, 1-7.

Li, Q., Guan, X., Wu, P., Wang, X., Zhou, L., Tong, Y., .. . Wong, J. Y. (2020). Early transmission dynamics in Wuhan, China, of novel coronavirus-infected pneumonia. New England Journal of Medicine. 382,1199-1207.

Ministry of Foreign Affairs of the Republic of Indonesia. (2020). Report of the Coronavirus. Jakarta: Ministry of Foreign Affairs of the Republic of Indonesia.

Ministry of Health of the Republic of Indonesia. Report of the Coronavirus. Jakarta: Ministry of Health of the Republic of Indonesia

Parry, J. (2020). China coronavirus: cases surge as official admits human to human transmission. In: British Medical Journal Publishing Group.368, m236

Strzelecki, A. (2020). Infodemiological study using google trends on coronavirus epidemic in Wuhan, China. arXiv preprint arXiv:2001.11021.

Wang, C., Horby, P. W., Hayden, F. G., \& Gao, G. F. (2020). A novel coronavirus outbreak of global health concern. The Lancet, 395(10223), 470-473.

World Health Organization. (2020). Novel Coronavirus (2019-nCoV): situation report, 3. Geneva: World Health Organization.

Zhu, N., Zhang, D., Wang, W., Li, X., Yang, B., Song, J., . . . Lu, R. (2020). A novel coronavirus from patients with pneumonia in China, 2019. New England Journal of Medicine.

Cite this article as: Tosepu, R., Effendy, D.S., Ahmad, L.O.A.I. (2020). The first confirmed cases of covid-19 in Indonesian citizens. Public Health of Indonesia. 6(2), 7071. https://dx.doi.org/10.36685/phi.v6i2.337 